\title{
Pengaruh Koneksi Politik terhadap Nilai Perusahaan Non-Keuangan
}

\author{
Joseline, Stanley Frandy, Stevanus Pangestu \\ Fakultas Ekonomi \& Bisnis, Universitas Katolik Indonesia Atma Jaya \\ Jl. Jend. Sudirman No.51, RT.5/RW.4, Karet Semanggi, Kecamatan Setiabudi, Kota Jakarta Selatan, \\ Daerah Khusus Ibukota Jakarta 12930
}

\section{Kata kunci: \\ Koneksi politik, nilai perusahaan, kinerja}

\section{Keywords: \\ Political connection, firm value, performance}

Corresponding author: pangestu@atmajaya.ac.id

\section{ABSTRAK}

Penelitian ini bertujuan untuk menganalisis pengaruh koneksi politik terhadap nilai perusahaan di perusahaan non-keuangan yang terdaftar di BEI pada periode 20172019. Pada penelitian ini, nilai perusahaan sebagai variabel dependen diukur menggunakan Tobin's Q. Variabel independen dalam penelitian ini adalah koneksi politik yang diukur dengan menggunakan rumus proporsi dewan direksi dan dewan komisaris yang terkoneksi politik. Analisis data ini dilakukan dengan menggunakan teknik regresi data panel pada perangkat lunak EViews 10.0 dengan jumlah sampel sebanyak 186 perusahaan non-keuangan dan dengan tahun penelitian 2017-2019 $(\mathrm{n}=558)$. Regresi panel dengan model random effect menunjukkan hasil bahwa koneksi politik memiliki pengaruh signifikan positif terhadap nilai perusahaan.

\section{ABSTRACT}

The purpose of this research is to study the effects of political connections on the value of publicly-traded non-financial companies in Indonesia, which was measured with Tobin's $Q$ ratio. The main regressor in this study was measured through politicallyconnected corporate board members. One hundred and eighty-six (186) publiclytraded non-financial companies were examined from 2017 to $2019(n=558)$. Data were analyzed using random effect panel regression on EViews econometric package. This investigation finds that that political connection positively influences firm value. 
Studi Akuntansi \& Keuangan Indonesia

\section{Pendahuluan}

Kelangsungan hidup perusahaan tidak terlepas dari ketergantungan dengan lingkungan di mana perusahan tersebut didirikan. Resource Dependence theory menekankan pentingnya menilai tingkat ketergantungan suatu perusahaan terhadap lingkungan atau sumber daya eksternal (Pfeffer \& Salancik, 1978) Dalam menjalankan aktivitas operasional perusahaan, terdapat pertimbangan yang mengharuskan perusahaan untuk menganalisis lingkungan eksternal perusahaan. Lingkungan eksternal di mana perusahaan beroperasi mencakup aspek politik (political), aspek ekonomi (economic), aspek sosial (social), aspek teknologi (technological), aspek lingkungan (environmental), dan aspek legalitas (legal). Di antara enam aspek lingkungan eksternal di atas, terdapat aspek politik yang tidak dapat dipandang sebelah mata, karena politik menyangkut kebijakan dan tindakan pemerintah dalam memengaruhi cara perusahaan beroperasi.

Politik menjadi salah satu sebab perkembangan kegiatan ekonomi melalui kebijakan fiskal dan kekuatan penguasa. Pernyataan ini didukung oleh Coulomb dan Sangnier (2014) yang menyatakan bahwa sebagian besar kegiatan politik memengaruhi perekonomian. Peristiwa maupun kejadian politik yang terjadi di suatu negara dapat memengaruhi stabilitas dan kinerja perekonomian negara, hal tersebut akan berdampak juga pada bisnis di negara tersebut. Politik dan bisnis menjadi dua hal yang tidak dapat dipisahkan. Politik memiliki tujuan untuk merumuskan kebijakan publik, salah satunya untuk kepentingan dunia bisnis. Sebaliknya, dunia bisnis dapat menunjang politik suatu negara (Wulandari \& Raharja, 2013). Politik memberikan dampak pada bisnis melalui pemerintah yang terus menerus menerapkan kebijakan ekonomi untuk mempertahankan pertumbuhan ekonomi negara. Seperti yang terjadi dalam hal bisnis ekspor-impor, pemerintah menetapkan peraturan dan kebijakan tertentu untuk melancarkan perusahaan yang menjalankan kegiatan ekspor-impor (Suyatna, 2019).

Keterkaitan politik dan bisnis seperti hubungan timbal balik, di mana peran politik dalam perumusan berbagai kebijakan yang dapat mendorong keberhasilan bisnis tetapi pelaku bisnis harus bersedia membantu partai politik dalam hal pendanaan sebagai konsekuensinya (Kurniasari, 2019). Partai politik tempat politikus bernaung membutuhkan dana dari pelaku bisnis untuk menjalankan aktivitas politik yang dilakukan. Begitu pula ketika seseorang ingin menjadi calon legislatif, presiden atau kepala daerah, calon tersebut membutuhkan peran pelaku bisnis untuk mendanai kampanye demi mengusung calon bersangkutan. Tentu saja pelaku bisnis berharapan mendapat bantuan yang menguntungkan bisnisnya ke depan ketika calon telah menduduki jabatan tertentu berupa kemudahan mendapatkan kontrak atau memenangkan proyek tender dari pemerintah (Sutopo et al., 2017). Ada juga pelaku bisnis yang melakukan lobi untuk kepentingan bisnisnya kepada politikus yang berkuasa. Hal tersebut terjadi karena pelaku bisnis yang berkepentingan dengan proyek-proyek pemerintah berusaha melancarkan izin proyeknya (Situmorang, 2009).

Hubungan antara bisnis dan politik yang telah dijelaskan di atas menyebabkan munculnya istilah perusahaan terkoneksi politik. Faccio dan Parsley (2009) menyatakan bahwa perusahaan yang memiliki koneksi politik akan mempunyai pangsa pasar yang besar. Politik sangat berperan dalam perusahan karena politik merupakan unsur ekonomi paling penting terutama dalam hal profitabilitas perusahaan (Agrawal \& Knoeber, 2015).Perusahaan yang terkoneksi politik akan lebih berpeluang menikmati pendapatan lebih tinggi dan produktivitas lebih besar. Konsisten dengan Resource Dependence theory, koneksi politik semakin banyak digunakan oleh bisnis sebagai sumber daya strategis untuk meningkatkan nilai perusahaan (Hillman, 2005). Di Indonesia sendiri, koneksi politik mulai berkembang setelah era reformasi. Studi seperti Harymawan dan Nowland (2016) juga menunjukkan Indonesia sebagai negara di mana dalam konteks bisnis, sangat dipengaruhi oleh politik. Bisnis di Indonesia sangat dipengaruhi oleh perubahan stabilitas politik dan efektivitas pemerintah.

Koneksi politik bagaikan pedang bermata dua karena koneksi politik dapat meningkatkan nilai perusahaan atau justru membahayakan nilai perusahaan. Berdasarkan Political Power theory yang diajukan oleh Siegfried (1972), ditemukan bahwa perusahaan dengan koneksi politik akan menggunakan kedekatan yang dimiliki untuk memperoleh manfaat yang tersedia di pasar. Perusahaan yang memiliki koneksi politik akan memperoleh manfaat seperti kurangnya pengawasan ketat yang memungkinkan keringanan pajak (Kim \& Zhang, 2016), penundaan pelaporan akuntansi (Leuz et al., 2003) serta lebih memudahkan proses pendanaan (Wijantini, 2007). Salah satu penelitian serupa yang diteliti oleh Li dan Xia (2013) menyatakan saat krisis ekonomi di negara Tiongkok terjadi, perusahaan yang terkoneksi politik memiliki kemudahan dalam memperoleh pinjaman modal dibandingkan dengan perusahaan yang tidak terkoneksi politik, sehingga 
Studi Akuntansi \& Keuangan Indonesia

perusahaan yang terkoneksi politik dapat meningkatkan nilai perusahaan yang terjadi karena adanya peningkatan harga saham.

Namun sebaliknya, koneksi politik juga dapat membahayakan nilai perusahaan. Chaney et al. (2011) menunjukkan bahwa kualitas informasi akuntansi dari perusahaan yang terkoneksi politik lebih rendah dibanding dengan perusahaan yang tidak terkoneksi politik. Hal ini menunjukkan bahwa intervensi politik dapat menyebabkan melemahnya praktik-praktik manajerial yang baik dan menyebabkan buruknya tata kelola perusahaan. Tata kelola perusahaan yang buruk dapat memengaruhi nilai perusahaan dalam jangka panjang (Velnampy \& Pratheepkanth, 2013). Chaney et al. (2011) juga menjelaskan bahwa terdapat kecenderungan perusahaan yang terkoneksi politik mendapatkan pengawasan yang lebih ketat dari pihak ketiga seperti regulator, pers, dan masyarakat, sehingga membuat perusahaan menjadi tidak dapat bebas.

Terdapat beberapa penelitian terkait yang telah menjelaskan dan memberikan bukti mengenai pengaruh hubungan politik terhadap nilai perusahaan. Penelitian Goldman et al. (2009) membuktikan bahwa hubungan politik memiliki pengaruh terhadap nilai perusahaan. Adapun penelitian yang dilakukan di Indonesia oleh Maulana dan Wati (2019) menyimpulkan bahwa terbukti ada pengaruh positif signifikan antara koneksi politik terhadap nilai perusahaan, hal ini konsisten dengan yang dikemukakan oleh (Fan et al., 2007; Maaloul et al., 2018) bahwa birokrat atau politisi menggunakan sumber daya dari perusahaan milik negara pimpinannya yang tercatat di bursa untuk memenuhi tujuan memaksimalkan nilai perusahaan. Penelitian Maaloul, Chakroun, dan Yahyaoui (2018) menunjukkan bahwa koneksi politik memperbaiki kinerja dan meningkatkan kekayaan pemegang saham.

Berbeda dengan penelitian sebelumnya yang menyatakan adanya pengaruh koneksi politik terhadap nilai perusahaan, (Dewanti, 2019) mendapatkan hasil bahwa koneksi politik tidak berpengaruh terhadap nilai perusahaan. Hasil ini mendukung penelitian milik Li dan Xia (2013) yang mana koneksi politik tidak berpengaruh signifikan terhadap nilai perusahaan. Begitu pula dengan hasil penelitian yang dilakukan Tangke (2019) yang menunjukkan bahwa koneksi politik memiliki pengaruh positif dan signifikan terhadap corporate social responsibility, namun tidak berpengaruh langsung terhadap nilai perusahaan.

Berdasarkan latar belakang yang telah dijelaskan terkait pro dan kontra koneksi politik serta adanya perbedaan hasil penelitian terdahulu, maka penulis ingin menguji kembali pengaruh koneksi politik terhadap nilai perusahaan.

\section{Telaah Literatur dan Pengembangan Hipotesis}

Penelitian Maulana dan Wati (2019) mengangkat isu pengaruh koneksi politik dan struktur kepemilikan manajerial terhadap nilai perusahaan berdasarkan fenomena praktik koneksi politik yang terjadi pada perusahaan-perusahaan manufaktur yang berada di Indonesia. Penelitian Maulana dan Wati (2019) mengukur variabel independen koneksi politik dengan menggunakan metode variabel dummy yang memberikan nilai 1 bagi perusahaan yang terkoneksi politik dan nilai 0 bagi perusahaan yang tidak terkoneksi politik. Variabel independen kepemilikan institusional diukur dengan menggunakan indikator persentase jumlah saham yang dimiliki institusi dari seluruh modal saham yang beredar di pasar saham. Sedangkan untuk mengukur variabel dependen nilai perusahaan digunakan rasio Tobin's $Q$. Hasil penelitian Maulana dan Wati (2019) menunjukkan bahwa koneksi politik memiliki pengaruh positif signifikan terhadap nilai perusahaan. Semakin tinggi koneksi politik maka semakin tinggi nilai perusahaan. Sementara kepemilikan manajerial terhadap nilai perusahaan tidak berpengaruh signifikan. Hal ini dikarenakan adanya agency conflict dan juga proporsi saham yang dimiliki oleh dewan direksi maupun komisaris sangat kecil dengan rata-rata hanya 0,03160 .

Penelitian Patriarini (2020) juga menemukan bahwa koneksi politik berpengaruh positif dan signifikan terkait dengan nilai perusahaan. Hasil menunjukkan bahwa koneksi politik yang dimiliki perusahaan dapat menyebabkan perusahaan memiliki keuntungan sehingga dapat meningkatkan nilai perusahaan. Variabel dependen penelitian Patriarini (2020) adalah nilai perusahaan yang diukur dengan rasio Tobin's $Q$ sementara variabel independen yang digunakan adalah koneksi politik. Politically Exposed Person (PEP) digunakan sebagai pengukuran perusahaan yang terkoneksi politik di Negara Indonesia. PEP dikategorikan seperti presiden, menteri, atau posisi setara gubenur, kepala partai politik, senior TNI atau polisi, senior kehakiman, dan hubungan dengan pihak yang memiliki koneksi politik satu garis (orang tua, saudara kandung, dan anak). Sehingga jika salah satu dari board of directors dan board of commissioners memiliki salah satu poin diatas maka skor 1, sedangkan perusahaan dengan skor 0 dinyatakan tidak terkoneksi politik. Adapun variabel kontrol penelitian adalah rasio return on equity (ROE) dan kantor akuntan publik 
Studi Akuntansi \& Keuangan Indonesia

yang menggunakan metode dummy di mana nilai 1 untuk yang di audit oleh Big Four dan nilai 0 untuk di audit selain Big Four.

Maaloul et al. (2018) juga melakukan penelitian mengenai pengaruh koneksi politik perusahaan pada kinerja keuangan dan saham serta pada nilai pasar dengan judul "The effect of political connections on companies' performance and value: evidence from Tunisian companies after the revolution". Variabel dependen dalam penelitian ini menggunakan rasio return on asset (ROA) untuk mengukur kinerja keuangan, rasio Tobin's $Q$ untuk mengukur kinerja pasar saham, dan $\log$ kapitalisasi pasar untuk mengukur nilai pasar suatu perusahaan. Variabel independen dalam penelitian ini adalah koneksi politik yang diukur dengan variabel dummy di mana nilai 1 untuk perusahaan yang terhubung secara politik dan nilai 0 untuk sebaliknya. Hasil penelitian Maaloul et al. (2018) menunjukkan bahwa koneksi politik meningkatkan kinerja dan nilai perusahaan. Hasil ini menjelaskan bahwa terdapat manfaat dan pertolongan yang dapat diperoleh perusahaan dari ikatan politik dan di sisi lain terdapat kecenderungan investor untuk berinvestasi di perusahaan yang terhubung secara politis. Investasi di perusahaan yang saling terhubung secara politis mungkin bermanfaat bagi investor, dan terutama bagi pemegang saham minoritas kecil.

Penelitian yang dilakukan (Dewanti, 2019; Harymawan et al., 2019) menyoroti peran koneksi politik terhadap hubungan antara perusahaan keluarga dan kinerja perusahaan di Indonesia. Temuan ini menghasilkan bahwa hubungan negatif antara perusahaan milik keluarga dengan kinerja perusahaannya. Namun di sisi lain, koneksi politik memiliki pengaruh positif terhadap kinerja perusahaan di Indonesia. Variabel dependen dalam penelitian ini adalah kinerja perusahaan yang diukur dengan rasio Tobin's $Q$. Variabel independen penelitian ini terdiri dari perusahaan keluarga yang diukur dengan variabel dummy begitu pula dengan variabel perusahaan terkoneksi politik yang diukur dengan variabel dummy.

Sementara itu penelitian Dewanti (2019) yang berjudul "Pengaruh Koneksi Politik Terhadap Nilai Perusahaan Yang Terdaftar di Bursa Efek Indonesia" membuktikan bahwa koneksi politik tidak berpengaruh signifikan terhadap nilai perusahaan yang diukur dengan PBV dan PER, dan jika diukur diukur dengan rasio Tobins' $Q$, koneksi politik juga tidak berpengaruh signifikan terhadap nilai perusahaan. Penelitian ini bertujuan menentukan pengaruh koneksi politik pada nilai perusahaan yang diukur dengan rasio Price to Book Ratio, Price to Earnings Ratio dan rasio Tobin's $Q$. Variabel kontrol dalam penelitian ini adalah ukuran perusahaan dan rasio Return on Equity (ROE).

Selanjutnya, penelitian yang diteliti oleh Li dan Xia (2013) berjudul "Political Connections, Financial Crisis and Firm's Value: Evidence from Chinese Listed Firms" menyatakan bahwa saat krisis ekonomi di negara Tiongkok terjadi, perusahaan yang terkoneksi politik memiliki kemudahan dalam memperoleh pinjaman modal dibandingkan dengan perusahaan yang tidak terkoneksi politik, sehingga dapat meningkatkan nilai perusahaan yang terjadi karena adanya peningkatan harga saham. Namun pada saat krisis ekonomi berakhir, keberadaan koneksi politik tidak mempengaruhi nilai perusahaan di Tiongkok. Penelitian ini meneliti dampak koneksi politik pada perusahaan sebelum dan sesudah krisis keuangan. Hasil penelitian ini menyimpulkan bahwa koneksi politik tidak berpengaruh signifikan terhadap nilai perusahaan yang diukur dengan rasio Tobin's $Q$.

Tangke (2019) menguji pengaruh koneksi politik dan kepemilikan asing terhadap nilai perusahaan melalui tanggung jawab sosial perusahaan dengan menggunakan data sekunder berupa laporan keuangan perusahaan non-keuangan yang terdaftar di Bursa Efek Indonesia untuk periode 2006-2015. Penelitian ini mengukur variabel independen koneksi politik dengan jumlah politisi atau kerabat dekat politisi yang menduduki jabatan direksi dan/atau komisaris dibagi dengan total jumlah direksi dan/atau komisari kemudian dikali dengan hasil pembobotan. Variabel independen kepemilikan asing diukur dengan pengukuran yang digunakan oleh Phung dan Hoang (2013) yaitu jumlah kepemilikan saham oleh pihak asing dibagi dengan jumlah saham yang beredar. Adapun variabel tanggung jawab sosial dalam penelitian ini diukur dengan Sustainability Reporting Guidelines (SRG). Dengan SRG inilah pengungkapan informasi tanggung jawab sosial pada laporan tahunan perusahaan diukur melalui pemberian skor. Sementara variabel dependen nilai perusahaan diukur dengan rasio Tobin's $Q$. Hasil penelitian ini menunjukkan bahwa koneksi politik memiliki pengaruh positif dan signifikan terhadap tanggung jawab sosial perusahaan tetapi tidak memiliki pengaruh signifikan terhadap nilai perusahaan. Sedangkan kepemilikan asing memiliki pengaruh positif dan signifikan terhadap tanggung jawab sosial dan nilai perusahaan. 
Studi Akuntansi \& Keuangan Indonesia

\section{Pengembangan Hipotesis}

Dalam Resource Dependence theory (RDT), Pfeffer dan Salancik (1978) menjelaskan perusahaan tidak dapat mengurangi ketidakpastian dan saling ketergantungan pada sistem sosial yang lebih besar (termasuk pemerintah), oleh karena itu mereka melakukan cara lain untuk mengurangi ketidakpastian dan saling ketergantungan terhadap lingkungan. Salah satu cara perusahaan mengurangi ketidakpastian dan saling ketergantungan dengan lingkungan eksternal adalah dengan membangun koneksi politik (Pfeffer \& Salancik, 1978; Hillman \& Dalziel, 2003). Konsisten dengan RDT, koneksi politik semakin banyak digunakan oleh bisnis sebagai salah satu sumber daya strategis untuk meningkatkan nilai perusahaan. Perusahaan yang memiliki koneksi politik memiliki banyak manfaat seperti yang sudah dijelaskan pada penelitian Kim dan Zhang (2016) yang menyatakan bahwa perusahaan akan mendapatkan perlindungan dari pemerintah, memudahkan proses pendanaan, risiko pemeriksaan pajak yang rendah, dan berbagai macam hak-hak istimewa yang dapat diperoleh perusahaan dengan koneksi politik. Bahkan saat terjadi krisis keuangan, perusahaan yang terkoneksi politik akan mudah mendapat dana pinjaman dari pemerintah (Li \& Xia, 2013).

Di Indonesia, pengaruh politik terhadap dunia bisnis cukup tinggi sesuai dengan yang dinyatakan Fisman (2001) yang menemukan bahwa koneksi politik mempengaruhi perusahaan di Indonesia dan menyebabkan adanya ketergantungan pada keuntungan dari koneksi yang diperoleh tersebut. Menurut Petriella (2015), jabatan komisaris terutama komisaris badan usaha milik negara banyak diduduki oleh para anggota partai, hal tersebut membuktikan bahwa perusahaan banyak memanfaatkan adanya koneksi politik untuk memperoleh keuntungan yang dapat memengaruhi nilai perusahaan.

Penelitian Faccio (2010) menyatakan bahwa koneksi politik memberikan pengaruh positif terhadap nilai perusahaan karena dengan adanya hak istimewa tersebut dapat membantu perusahaan meningkatkan nilai perusahaannya. Sesuai dengan penelitian Maulana dan Wati (2019), koneksi politik memiliki pengaruh positif signifikan terhadap nilai perusahaan. Begitu juga dengan penelitian Maaloul et al. (2018) yang menunjukkan bahwa koneksi politik meningkatkan kinerja dan nilai perusahaan. Di samping itu, Patriarini (2020) juga menemukan bahwa koneksi politik berpengaruh positif dan signifikan terkait dengan nilai perusahaan.

Berdasarkan fenomena dan hasil penelitian yang dilakukan oleh peneliti terdahulu, maka hipotesis yang dibangun oleh penelitian ini adalah sebagai berikut:

$H_{1}$ : Koneksi politik berpengaruh positif terhadap nilai perusahaan.

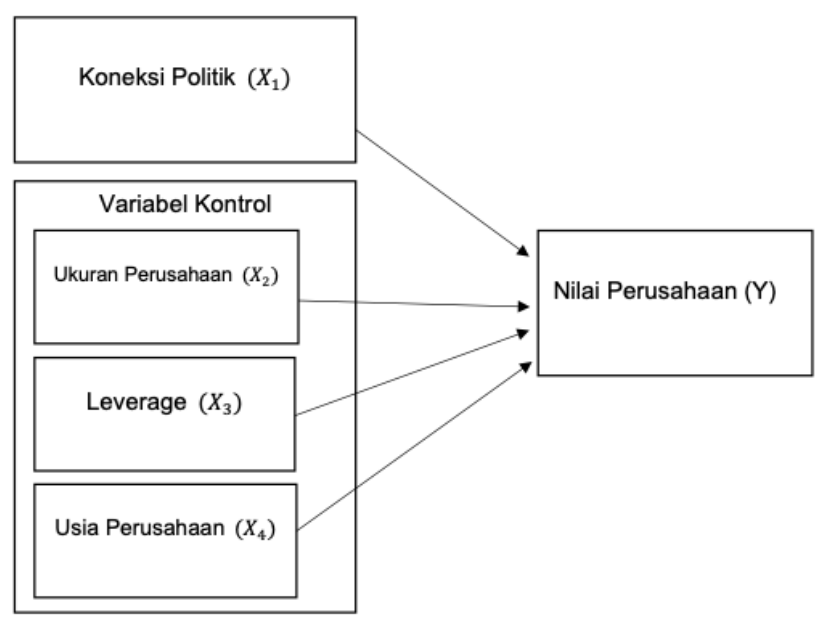

Gambar 1. Kerangka Pemikiran 


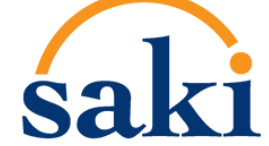

Studi Akuntansi \& Keuangan Indonesia

\section{Metode Penelitian}

\section{Populasi dan Sampel}

Penelitian ini merupakan studi kuantitatif menggunakan data sekunder yang diperoleh dari laporan tahunan perusahaan non-keuangan yang terdaftar di Bursa Efek Indonesia selama tahun 2017 hingga 2019. Definisi operasional variabel dapat dilihat pada Tabel 1.

Populasi dalam penelitian ini ialah seluruh perusahaan non-keuangan yang terdaftar pada Bursa Efek Indonesia pada tahun 2017 hingga 2019. Jumlah sampel minimum ditentukan mengikuti tabel Krejcie dan Morgan (1970) dalam penentuan jumlah sampel dengan jumlah populasi tertentu. Perusahaan dipilih secara purposive dan data yang diperoleh kemudian diolah menggunakan regresi panel untuk menguji model.

\section{Operasionalisasi Variabel}

Dalam mengukur variabel dependen nilai perusahaan, digunakan rasio Tobin's $Q$, yang diperoleh dari jumlah nilai pasar ekuitas dan liabilitas dibagi dengan jumlah nilai buku ekuitas dan liabilitas (Damodaran, 2012). Jika hasil perhitungan rasio Q melebihi 1, maka dapat diartikan bahwa emiten dinilai lebih besar dibandingkan dengan nilai bukunya.

Dalam mengukur variabel independen koneksi politik, anggota dewan direksi maupun komisaris akan diperhitungkan karena di Indonesia menggunakan sistem tata kelola dewan two-tier. Direktur atau komisaris akan diperhitungkan memiliki koneksi politik apabila: (i) merupakan anggota legislatif, (ii) berasosiasi dengan partai politik, (iii) memiliki pengalaman eksekutif/legislatif/yudikatif di pemerintahan, (iv) memiliki pengalaman di BUMN atau Persero, atau (v) merupakan suami, istri, orangtua, anak, atau saudara kandung dari seorang politikus. Jika seorang anggota dewan memenuhi salah satu dari lima kriteria yang disebutkan, maka ia dianggap memiliki koneksi politik. Cara pengukuran ini dikembangkan dari Faccio (2010). Setelah mentabulasi jumlah direktur yang memiliki koneksi politik, maka proporsi dewan yang terkoneksi politik akan dihitung dengan cara membagi jumlah anggota dewan yang terkoneksi politik dengan jumlah anggota dewan perusahaan.

Dalam persamaan regresi penelitian ini juga menggunakan variabel kontrol ukuran perusahaan, leverage, dan usia perusahaan. Variabel ukuran perusahaan diukur dengan total aset. Untuk tujuan regresi, logaritma natural dari total aset akan digunakan. Variabel kontrol leverage diukur menggunakan rasio debtto-equity, yaitu membagi total liabilitas dengan total ekuitas. Variabel kontrol usia perusahaan dihitung dari selisih tahun observasi dengan tahun perusahaan melakukan penawaran umum perdana (initial public offering).

Tabel 1. Pemilihan Sampel

\begin{tabular}{lll}
\hline No. & Kriteria & Jumlah perusahaan \\
\hline 1 & Perusahaan non-keuangan di BEI pada tahun 2017 & 406 \\
2 & Laporan tahunan yang tidak dapat diperoleh & $(38)$ \\
3 & Emiten yang memperoleh ekuitas negatif & $(17)$ \\
& Jumlah Populasi memenuhi kriteria & 351 \\
& Jumlah Sampel merujuk tabel Krejcie-Morgan & 186 \\
& Periode Observasi & 3 \\
\hline
\end{tabular}

\section{Hasil dan Diskusi}

Objek penelitian dalam penelitian ini adalah perusahaan yang bergerak dalam seluruh sektor nonkeuangan dan terdaftar di Bursa Efek Indonesia pada tahun 2017-2019 sebanyak 406 perusahaan. Dari 406 perusahaan non-keuangan tersebut, terdapat 351 perusahaan yang memenuhi kriteria populasi sehingga terdapat 55 perusahaan yang tidak digunakan sebagai populasi penelitian. Hal ini dikarenakan terdapat 38 perusahaan yang laporan tahunannya tidak dapat diakses baik melalui situs resmi Bursa Efek Indonesia maupun situs resmi emiten terkait dan 17 perusahaan memperoleh ekuitas negatif selama tahun 2017-2019. 
Studi Akuntansi \& Keuangan Indonesia

Dari populasi yang sesuai kriteria, melalui purposive sampling, ditentukan 186 perusahaan sebagai sampel penelitian di mana penentuan besaran sampel penelitian dilakukan dengan tabel jumlah sampel berdasarkan jumlah populasi oleh Krejcie dan Morgan (1970).

Tabel 2. Statitistika Deskriptik

\begin{tabular}{lccccc}
\hline & Mean & Maximum & Minimum & $\begin{array}{l}\text { Standard } \\
\text { Deviation }\end{array}$ & N \\
\hline Tobin's Q & 1,366558 & 14,62141 & 0,227632 & 1,116811 & 558 \\
PC & 0,147939 & 1,000000 & 0,000000 & 0,240800 & 558 \\
SIZE & 15,33510 & 19,21461 & 9,622492 & 1,645164 & 558 \\
DER & 1,107873 & 3,944700 & 0,008531 & 0,935477 & 558 \\
AGE & 15,87097 & 39,00000 & 0,000000 & 9,432241 & 558 \\
\hline
\end{tabular}

Tabel 2 di atas menunjukkan bahwa nilai nilai rata-rata yang diperoleh dari 186 perusahaan dengan menggunakan Tobin's Q adalah sebesar 1,366558. Artinya, rata-rata perusahaan dinilai oleh pelaku pasar lebih tinggi dibandingkan dengan nilai aset perusahaan yang tercatat. Nilai mean dari variabel koneksi politik menunjukkan sebesar 0,142276. Nilai tersebut memiliki arti bahwa sebesar 14,8\% dewan direksi dan dewan komisaris merupakan dewan direksi dan dewan komisaris yang terkoneksi politik.

Untuk melihat hubungan antara variabel, hasil pengujian regresi dapat dilihat pada Tabel 3 di bawah. Sebelumnya juga telah dilakukan beberapa pengujian dan ditemukan bahwa model regresi: (i) memiliki residual yang terdistribusi secara normal, (ii) tidak memiliki multikolinearitas sempurna, (iii) keragaman galat bersifat homoskedastis, dan (iv) tidak ditemukan masalah autokorelasi.

Tabel 3 Hasil Regresi

\begin{tabular}{llll}
\hline Estimation & Pooled OLS & Fixed Effects Panel & Random Effects Panel \\
\hline C & 2,3323 & 4,2181 & 2,4778 \\
PC & $(5,2334)$ & $(1,1279)$ & $(3,6582)$ \\
& 0,9676 & 0,8727 & 0,9820 \\
SIZE & $(4,7945)^{* * *}$ & $(1,1922)$ & $(3,3831)^{* * *}$ \\
& $-0,0646$ & $-0,1244$ & $-0,0723$ \\
DER & $(-2,1720)^{* * *}$ & $(-0,4765)$ & $(-1,5985)$ \\
& $-0,1248$ & $-0,0443$ & $-0,1062$ \\
AGE & $(-2,4812)^{* *}$ & $(-0,3971)$ & $(-1,6733)^{*}$ \\
& 0,0012 & $-0,0644$ & $-0,0019$ \\
F-statistic & $(0,2560)$ & $(-1,7991)^{*}$ & $(-0,2474)$ \\
Redundant fixed effects & - & $7,9872^{* * *}$ & $3,8638^{* * *}$ \\
Chi-square statistic & $7,3591^{* * *}$ & 880,4107 & - \\
Hausman Chi-square & - & $(\mathrm{p}$-value: 0,00$)$ & \\
statistic & - & 4,68 \\
S.E. of Regression & 1,0921 & 0,6082 & $(\mathrm{p}$-value: 0,3217$)$ \\
Adjusted R-squared & 0,0436 & 0,7033 & 0,6087 \\
\hline ***menandakan signifikan pada 1\%,**signifikan pada 5\%, *signifikan pada $10 \%$ \\
Jumlah periode: 3 & $\mid$ Jumlah sampel perusahaan: $186 \quad \mid$ Jumlah observasi balanced: 558 \\
\hline
\end{tabular}


Studi Akuntansi \& Keuangan Indonesia

Berdasarkan analisis data dengan menggunakan regresi panel random effect model yang terlihat pada Tabel 4, diketahui bahwa koneksi politik yang diukur dengan rumus proporsi dewan direksi dan dewan komisaris yang terkoneksi politik berpengaruh signifikan terhadap nilai perusahaan yang diukur dengan Tobin's Q. Hasil ini dapat terlihat dari $p$-value yang lebih kecil dari tingkat signifikansi $(\alpha=5 \%)$. Pengaruh bersifat positif signifikan karena nilai pada koefisien regresi pada tabel 4 sebesar 0,982031. Artinya, semakin tinggi koneksi politik yang dimiliki perusahaan maka semakin tinggi pula nilai perusahaan tersebut.

Koneksi politik menyebabkan adanya keterkaitan dan keterlibatan perusahaan dalam lingkungan politik yang dapat membangun nilai perusahaan. Terdapat alasan yang dapat menjelaskan bahwa perusahaan yang terkoneksi politik memiliki nilai perusahaan yang lebih menarik bagi investor daripada perusahaan yang tidak terkoneksi politik. Pertama, perusahaan terkoneksi politik akan memperoleh perlindungan berupa diberinya kemudahan dalam regulasi sehingga perusahaan dapat meningkatkan nilai perusahaannya. Menurut Goldman et al. (2009), keberadaan orang-orang yang terkoneksi politik dalam susunan dewan komisaris dan dewan direksi perusahaan dapat mempermudah akses untuk mendapatkan perizinan, kontrak atau memenangkan tender proyek yang berhubungan dengan proyek pemerintah.

Kedua, perusahaan yang terkoneksi politik memperoleh keuntungan, salah satunya adalah kemudahan dalam proses pendanaan, hal ini sejalan dengan yang dinyatakan (Wijantini, 2007). Pendanaan dibutuhkan oleh perusahaan untuk keperluan ekspansi bisnis, inovasi bisnis, maupun keperluan operasional. Adanya koneksi politik dalam suatu perusahaan yang memberikan keuntungan-keuntungan yang dapat digunakan sebagai salah satu cara untuk meningkatkan harga saham, yang di mana dengan meningkatnya harga saham maka nilai perusahaan juga akan ikut meningkat. Keuntungan yang diterima inilah yang menyebabkan investor tertarik pada perusahaan terkoneksi politik serta mendorong kepercayaan bahwa dengan adanya koneksi politik dapat memberikan keuntungan bagi para pemegang saham. Investor yang membeli saham perusahaan terkoneksi politik dapat meningkatkan permintaan di pasar saham, di mana meningkatnya permintaan saham akan meningkatkan harga saham sehingga dapat mempengaruhi nilai perusahaan.

Ketiga, perusahaan terkoneksi politisi akan memberikan petunjuk atau sinyal kepada investor dengan adanya penyajian informasi kepada publik terkait dewan komisaris atau dewan direksi yang memiliki hubungan politik. Lebih lanjut, ini juga sesuai dengan signalling theory (Spence, 1973) yang menyatakan bahwa perusahaan akan memberikan informasi terkait dewan direksi dan dewan komisaris sebagai suatu sinyal positif yang memberikan petunjuk kepada investor dalam pengambilan keputusan investasi. Apabila sinyal tersebut positif maka akan ditangkap dan direspons oleh investor yang ditunjukkan dengan adanya peningkatan permintaan saham di pasar. Dewan komisaris dan dewan direksi yang terkoneksi politik yang sudah terbukti dengan citra positif yang dimilikinya dapat menimbulkan kepercayaan publik terhadap perusahaan tersebut sehingga akan menjadi suatu sinyal positif yang meningkatkan nilai perusahaan.

Hasil penelitian ini sesuai dengan Resource Dependence theory sebagai landasan teori model penelitian, di mana koneksi politik dianggap sumber daya tak berwujud yang memungkinkan perusahaan memperoleh dukungan dari pemerintah dan menghasilkan keunggulan kompetitif serta peningkatan nilai perusahaan untuk mengurangi ketidakpastian dan saling ketergantungan terhadap lingkungan. Perusahaan yang terkoneksi politik dianggap sebagai perusahaan yang menyesuaikan diri dengan menggunakan sumber daya strategis dari lingkungan eksternal untuk meningkatkan nilai perusahaan yang dapat memberikan sinyal positif bagi para investor dan pengguna informasi lainnya. Dengan demikian, semakin banyak direksi dan komisaris yang terkoneksi politik dalam suatu perusahaan maka hal tersebut akan berpengaruh positif bagi investor untuk bahan pertimbangan dalam melakukan investasi terhadap perusahaan tersebut dan secara bersamaan nilai perusahaan akan ikut meningkat.

\section{Kesimpulan, Implikasi, dan Keterbatasan}

Berdasarkan hasil penelitian yang telah diuraikan, dapat dinyatakan bahwa nilai perusahaan akan semakin tinggi apabila koneksi politik yang dimiliki perusahaan semakin tinggi, hal ini disebabkan oleh tingkat kepercayaan investor bahwa perusahaan terkoneksi politik akan memperoleh perlindungan dan keuntungan dari politisi dalam pemerintah yang menjabat sebagai dewan komisaris atau dewan direksi dalam perusahaan.

Adanya perlindungan dan keuntungan yang diperoleh, perusahaan terkoneksi politik dapat meningkatkan kepercayaan dan minat investor untuk berinvestasi yang di mana secara bersamaan akan meningkatkan nilai perusahaan. Hasil penelitian ini juga mendukung Resource Dependence theory di mana 
Studi Akuntansi \& Keuangan Indonesia

koneksi politik dianggap sebagai sumber daya eksternal yang memungkinkan perusahaan memperoleh dukungan dari pemerintah dan menghasilkan keunggulan kompetitif serta peningkatan nilai perusahaan untuk mengurangi ketidakpastian dan saling ketergantungan terhadap lingkungan.

Keterbatasan dalam penelitian ini ialah pada pengambilan sampel perusahaan non-keuangan, sehingga hasil belum bisa digeneralisasi. Penelitian selanjutnya juga dapat menambahkan beberapa determinan nilai perusahaan sebagai variabel untuk mengurangi bias model. Sektor Keuangan juga menarik untuk diteliti. Sedangkan implikasi yang dapat dipertimbangkan oleh para pemangku kepentingan, terutama investor, ialah mencermati anggota direksi yang memiliki pengalaman maupun jejaring politik, karena ini berpotensi dapat meningkatkan nilai perusahaan.

\section{Daftar Pustaka}

Agrawal, A., \& Knoeber, C. R. (2015). Do Some Outside Directors Play a Political Role?*. The Journal of Law and Economics, 44(1), 179-198. https://doi.org/10.1086/320271

Chaney, P. K., Faccio, M., \& Parsley, D. (2011). The quality of accounting information in politically connected firms. Journal of Accounting and Economics, 51(1-2), 58-76. https://doi.org/10.1016/J.JACCECO.2010.07.003

Coulomb, R., \& Sangnier, M. (2014). The impact of political majorities on firm value: Do electoral promises or friendship connections matter? Journal of Public Economics, 115, 158-170. https://doi.org/10.1016/J.JPUBECO.2014.05.001

Damodaran, A. (2012). Investment Valuation: Tools and Techniques for Determining the Value of Any Asset, 3rd Edition. Wiley.

Dewanti, M. R. (2019). Pengaruh Koneksi Politik Terhadap Nilai Perusahaan Yang Terdaftar Di BEI.

Faccio, M. (2010). Differences between Politically Connected and Nonconnected Firms: A Cross-Country Analysis. Financial Management, 39(3), 905-928. https://doi.org/10.1111/J.1755-053X.2010.01099.X

Faccio, M., \& Parsley, D. C. (2009). Sudden Deaths: Taking Stock of Geographic Ties. Journal of Financial and Quantitative Analysis, 44(3), 683-718. https://doi.org/10.1017/S0022109009990068

Fan, J. P. H., Wong, T. J., \& Zhang, T. (2007). Politically connected CEOs, corporate governance, and Post-IPO performance of China's newly partially privatized firms. Journal of Financial Economics, 84(2), 330-357. https://doi.org/10.1016/J.JFINECO.2006.03.008

Fisman, R. (2001). Estimating the Value of Political Connections. The American Economic Review, 91(4), 1095-1102. http://www.jstor.org/stable/2677829

Goldman, E., Rocholl, J., \& So, J. (2009). Do Politically Connected Boards Affect Firm Value? The Review of Financial Studies, 22(6), 2331-2360. https://doi.org/10.1093/RFS/HHN088

Harymawan, I., Nasih, M., Madyan, M., \& Sucahyati, D. (2019). The Role of Political Connections on Family Firms' Performance: Evidence from Indonesia. International Journal of Financial Studies 2019, Vol. 7, Page 55, 7(4), 55. https://doi.org/10.3390/IJFS7040055

Harymawan, I., \& Nowland, J. (2016). Political connections and earnings quality How do connected firms respond to changes in political stability and government effectiveness? International Journal of Accounting \& Information Management, 24(4), 339-356. https://doi.org/10.1108/IJAIM-05-2016-0056

Hillman, A. J. (2005). Politicians on the Board of Directors: Do Connections Affect the Bottom Line? Journal of Management, 31(3), 464-481. https://doi.org/10.1177/0149206304272187

Hillman, A. J., \& Dalziel, T. (2003). Boards of Directors and Firm Performance: Integrating Agency and Resource Dependence Perspectives. The Academy of Management Review, 28(3), 383. https://doi.org/10.2307/30040728

Kim, C., \& Zhang, L. (2016). Corporate Political Connections and Tax Aggressiveness. Contemporary Accounting Research, 33(1), 78-114. https://doi.org/10.1111/1911-3846.12150

Krejcie, R. v., \& Morgan, D. W. (1970). Determining Sample Size for Research Activities: Educational and Psychological Measurement, 30(3), 607-610. https://doi.org/10.1177/001316447003000308

Kurniasari, S. (2019). Pengaruh Koneksi Politik Terhadap Kinerja Perusahaan Dengan Kepemilikan Publik Sebagai Variabel Moderasi.

Leuz, C., Nanda, D., \& Wysocki, P. D. (2003). Earnings management and investor protection: an international comparison. Journal of Financial Economics, 69(3), 505-527. https://doi.org/10.1016/S0304-405X(03)00121-1

Li, A., \& Xia, X. (2013). Political Connections, Financial Crisis and Firm's Value: Evidence from Chinese Listed Firms. International Journal of Business and Management, 8(18), p63. https://doi.org/10.5539/IJBM.V8N18P63

Maaloul, A., Chakroun, R., \& Yahyaoui, S. (2018). The effect of political connections on companies' performance and value: Evidence from Tunisian companies after the revolution. Journal of Accounting in Emerging Economies, 8(2), 185-204. https://doi.org/10.1108/JAEE-12-2016-0105/FULL/PDF 
Studi Akuntansi \& Keuangan Indonesia

Maulana, A., \& Wati, L. N. (2019). Pengaruh Koneksi Politik dan Struktur Kepemilikan Manajerial terhadap Nilai Perusahaan. Jurnal Akuntansi, 8(1), 1-12. https://doi.org/10.37932/JA.V8I1.59

Patriarini, W. E. (2020). Pengaruh Koneksi Politik terhadap Nilai Perusahaan. E-Jurnal Akuntansi, 30(6), 1550-1560. https://doi.org/10.24843/EJA.2020.V30.I06.P16

Petriella, Y. (2015, March 20). Sejumlah Politikus Duduki Jabatan Komisaris \& Direksi BUMN - Finansial Bisnis.com. https://finansial.bisnis.com/read/20150320/90/413841/sejumlah-politikus-duduki-jabatan-komisarisdireksi-bumn

Pfeffer, J., \& Salancik, G. R. (1978). The External Control of Organizations: A Resource Dependence Perspective. Harper \& Row.

Phung, D. N., \& Hoang, T. P. T. (2013, September 28). Corporate Ownership and Firm Performance in Emerging Market: A Study of Vietnamese Listed Firms. SSRN Electronic Journal. https://doi.org/10.2139/SSRN.2332622

Siegfried, J. J. (1972). The relationship between economic structure and the effect of political influence : empirical evidence from the Federal corporation income tax program [[S.1.]]. https://www.econbiz.de/Record/therelationship-economic-structure-effect-political-influence-empirical-evidence-federal-corporation-income-taxprogram-siegfried-john/10004839864

Situmorang, J. R. (2009). Beberapa Keterkaitan Antara Politik dan Bisnis. Jurnal Administrasi Bisnis, 50-63. https://doi.org/https://doi.org/10.26593/jab.v5i2.2111.\%25p

Spence, M. (1973). Job Market Signaling. The Quarterly Journal of Economics, 87(3), 355-374.

Sutopo, B., Trinugroho, I., \& Damayanti, S. M. (2017). Politically Connected Banks: Some Indonesian Evidence. International Journal of Business and Society, 18(1), 83-94. https://doi.org/10.33736/IJBS.491.2017

Suyatna, U. (2019). Implementasi Kebijakan Ekspor Perdagangan di Indonesia. Sosiohumaniora, 21(2), $173-183$. https://doi.org/10.24198/SOSIOHUMANIORA.V21I2.19370

Tangke, P. (2019). Pengaruh Politial Connection dan Foreign Ownership terhadap Nilai Perusahaan Melalui Corporate Social Responsibility. Jurnal Akuntansi Dan Keuangan Daerah, 14(1), 1-15. https://doi.org/10.52062/JAKD.V14I1.1442

Velnampy, T., \& Pratheepkanth, P. (2013). Corporate Governance and Firm Performance: “A Study of Selected Listed Companies in Sri Lanka.” European Jounral of Commerce and Management Research, 2(6), 123-127. www.ejcmr.org

Wijantini. (2007). A Test of the Relationship between Political Connection and INdirect Costs of Financial Distress in Indonesia. AAMJAF, 3(2), 61-81.

Wulandari, T., \& Raharja. (2013). Analisis Pengaruh Political Connection dan Struktur Kepemilikan terhadap Kinerja Perusahaan. Diponegoro Journal of Accounting.

https://ejournal3.undip.ac.id/index.php/accounting/article/view/2290/2309 